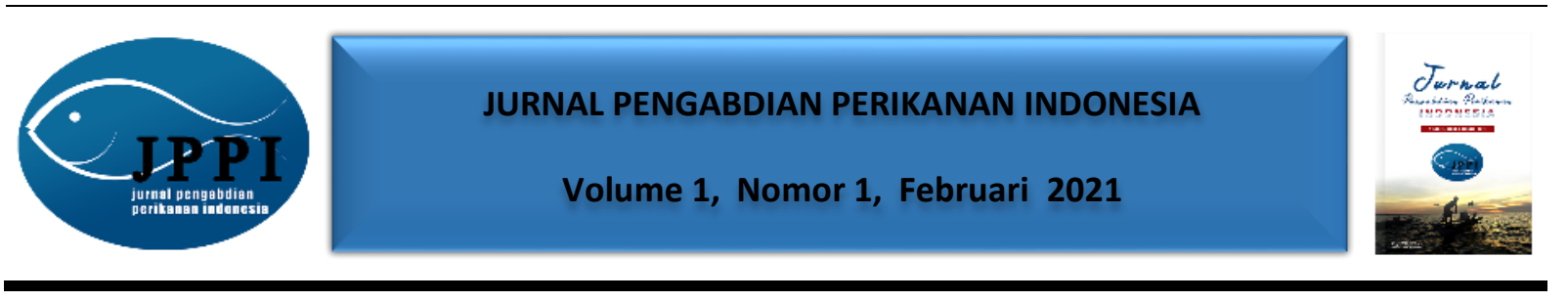

\title{
PENGEMBANGAN TEKNOLOGI INSTALASI AKUAPONIK MENGGUNAKAN MODEL NFT (NUTRIENT FILM TECHNIQUE) DI DESA GONTORAN KECAMATAN LINGSAR, LOMBOK BARAT
}

\author{
Fariq Azhar ${ }^{1}$, Alis Muklis ${ }^{1}$, Salnida Yuniarti Lumbessy ${ }^{1}$, Dewi Nura'eni Setyowati ${ }^{1}$,Dewi Putri \\ Lestari $^{1}$
}

\author{
Program Studi Budidaya Perairan, Universitas Mataram \\ Jalan Pendidikan Nomor 37 Kota Mataram
}

Alamat korespondensi : fariqazhar@unram.ac.id

(Tanggal Submission: 3 Desember 2020, Tanggal Accepted : 2 Februari 2021)

\begin{abstract}
Keyword: Abstrak:
budidaya, Desa Gontoran Kecamatan Lingsar merupakan salah satu kecamatan di Kabupaten akuaponik, Lombok Barat yang termasuk daerah dengan mayoritas mata pencaharian Nutrient masyarakatnya adalah petani dan pembudidaya. Selain faktor ketersediaan air yang Film melimpah, lahan pertanian dan pekarangan rumah warga juga cukup luas sehingga Technique banyak dimanfaatkan untuk pembuatan kolam dalam usaha budidaya ikan, salah satunya adalah kegiatan budidaya perikanan yang dilakukan oleh kelompok usaha Milenial Jaya. Namun harga pasaran ikan masih diangka rata-rata sedangkan biaya produksi cukup besar sehingga kegiatan budidaya masih belum bisa mensejahterakan kehidupan masyarakat sekitar. Dengan demikian perlu adanya alternatif cara untuk mengembangkan usaha masyarakat mitra melalui pengembangan usaha berkebun dengan teknologi instalasi akuaponik model NFT (Nutrient Film Technique) di pekarangan rumah. Penyuluhan yang dilakukan di Desa Gontoran Kecamatan Lingsar Kabupaten Lombok Barat ini dilakukan dengan metode Focus Group Discussion (FGD) dengan menyampaikan informasi kepada pembudidaya terkait instalasi akuaponik. Hasil dari kegiatan ini cukup baik yaitu dengan meningkatnya pendapatan para pembudidaya, terbukanya wawasan serta keterampilan para pembudidaya terkait kegiatan budidaya berkelanjutan dan manajemen usaha yang tepat.
\end{abstract}

Panduan Sitasi (APPA $7^{\text {th }}$ edition) :

Azhar, F., Muklis, A., Lumbessy, S.Y., Setyowati, D.N., \& Lestari, D.P. (2021). Pengembangan Teknologi Instalasi Akuaponik Menggunakan Model Nft (Nutrient Film Technique) Di Desa Gontoran Kecamatan Lingsar, Lombok Barat. Jurnal Pengabdian Perikanan Indonesia, 1 (1), 81-87. http://doi.org/ 10.29303/jppi.v1i1.44 


\section{PENDAHULUAN}

Desa Gontoran Kecamatan Lingsar merupakan salah satu kecamatan di Kabupaten Lombok Barat yang termasuk daerah dengan mayoritas mata pencaharian masyarakatnya adalah petani dan pembudidaya. Selain faktor ketersediaan air yang melimpah, lahan pertanian dan pekarangan rumah warga juga cukup luas sehingga banyak dimanfaatkan untuk pembuatan kolam dalam usaha budidaya ikan. Usaha budidaya ikan yang dilakukan biasanya berfokus pada budidaya ikan nila mulai dari usaha pembenihan hingga usaha pembesaran. Pada umumnya di daerah ini usaha budidaya lebih dominan dilakukan oleh para laki-laki, sedangkan para perempuan hanya bekerja sebagai ibu rumah tangga dan membantu suaminya sebagai pelaku budidaya untuk memasarkan dan mengolah hasil budidaya ikan.

Dari hasil survey yang dilakukan di desa Gontoran Kecamatan Lingsar, terdapat kelompok Budidaya Perikanan Milenial Jaya yang terdiri dari 15 kepala keluarga dan sudah berdiri sejak tahun 2015. Dari hasil wawancara yang telah dilakukan dengan salah satu anggota kelompok, diketahui bahwa kendala yang dihadapi para pembudidaya adalah harga pasaran ikan masih diangka rata-rata sedangkan biaya produksi cukup besar sehingga kegiatan budidaya masih belum bisa mensejahterakan kehidupan masyarakat sekitar. Dengan tidak adanya kegiatan yang dilakukan oleh para istri pembudidaya selain memasarkan dan mengolah hasil budidaya yang dilakukan oleh suaminya dan hasil panen ikan yang masih diangka rata-rata merupakan permasalahan yang menyebabkan kurang sejahteranya kehidupan pembudidaya dari segi ekonomi.

Berdasarkan latar belakang di atas, perlu dilakukannya pemberdayaan masyarakat khususnya ibu rumah tangga atau istri pembudidaya kelompok Budidaya Perikanan Milenial Jaya melalui usaha berkebun dengan teknologi instalasi akuaponik di pekarangan rumah menggunakan model NFT (Nutrient Film Technique) untuk memperkuat perekonomian warga dengan memanfaatan lahan yang ada, dan memberikan sosialisasi terkait dengan masa emas panen, serta management usaha penjualan ikan yang dapat mengoptimalkan pendapatan pembudidaya.

Menurut Saparianto et al. (2014), Akuaponik merupakan kombinasi sistem akuakultur dan budidaya tanaman tanpa harus menggunakan tanah sebagai media tanam tanaman, atau dapat diartikan sebagai perpaduan usaha antara budidaya ikan dan bertanam sayuran. Hanya saja perolehan nutrisi sayuran lebih ditekankan pada pemanfaatan sumber air dari budidaya ikan, karena pada air sisa kotoran dan pakan ikan dapat menjadi bahan nutrisi bagi sayuran, sehingga dapat menghasilkan produk organik. Inti dari sistem teknologi akuaponik adalah penyediaan air yang optimum untuk masing-masing komoditas, baik ikan budidaya maupun tanaman budidaya dengan memanfaatkan sistem resirkulasi. Menurut Nugroho et al. (2012), fungsi resirkulasi pada sistem akuaponik sangat berkaitan erat dengan proses pencucian sampah-sampah sisa metabolisme ikan (faeces) dan sisa-sisa pakan yang tidak tercerna. Menurut Dauhan et al. (2014), sistem akuaponik mereduksi amonia dengan cara menyerap air buangan budidaya atau air limbah menggunakan akar tanaman sehingga amonia yang terserap mengalami proses oksidasi dengan bantuan oksigen dan bakteri, kemudian amonia diubah menjadi nitrat.

Handayani (2018) menyatakan, sistem aquaponik dalam skala kecil dapat bermanfaat untuk rumah tangga dan dalam skala besar dapat dimanfaatkan untuk kebutuhan komersial. Beberapa media tanam yang dapat digunakan dalam budidaya tanpa tanah ini diantaranya adalah media air, pakis, arang, kerikil, sekam, styrofoam, pipa/paralon, dan bahan-bahan lainnya selain tanah (Sulistyo, 2016).

Analisa Situasi dan Permasalahan Masyarakat Sasaran/Mitra 
Pembudidaya ikan di Desa Gontoran Kecamatan Lingsar merupakan pembudidaya ikan yang sehari-harinya bekerja sebagai petani. Kegiatan budidaya ikan dilakukan untuk mengisi waktu luang mereka setelah bercocok tanam. Dari hasil wawancara yang telah dilakukan diketahui bahwa kendala yang dihadapi para pembudidaya adalah harga pasaran ikan masih diangka rata-rata sedangkan biaya produksi cukup besar sehingga kegiatan budidaya masih belum bisa mensejahterakan kehidupan masyarakat sekitar. Dengan tidak adanya kegiatan yang dilakukan oleh para istri pembudidaya selain memasarkan dan mengolah hasil budidaya yang dilakukan oleh suaminya dan hasil panen ikan yang masih diangka rata-rata merupakan permasalahan yang menyebabkan kurang sejahteranya kehidupan pembudidaya dari segi ekonomi.

Salah satu kegiatan yang akan dilakukan pada pengabdian kali ini adalah memberikan informasi mengenai pengembangan usaha berkebun dengan teknologi instalasi akuaponik model NFT (Nutrient Film Technique) di pekarangan rumah yang dapat dilakukan oleh para istri pembudidaya. Pembudidaya ikan desa Gontoran akan diberikan pelatihan pembuatan instalasi akuaponik model NFT (Nutrient Film Technique) di pekarangan rumah. Proses yang dilakukan juga cukup mudah, karena bahan yang diperlukan dapat diperoleh disekitar desa tersebut. Dengan adanya pendekatan seperti ini diharapkan menambah pengetahuan dan ketrampilan masyarakat mitra dalam kegiatan usaha ekonomi produktif.

\section{METODE KEGIATAN}

Kegiatan penyuluhan ini akan dilaksanakan di desa Gontoran, Kecamatan Lingsar, Lombok Barat Nusa Tenggara Barat. Penyuluhan dilaksanakan dengan menyampaikan informasi kepada masyarakat tentang pengembangan usaha berkebun dengan teknologi instalasi akuaponik model NFT (Nutrient Film Technique) di pekarangan rumah. Metode yang digunakan dalam penyuluhan ini adalah Focus Group Discusion (FGD) dengan memberikan informasi atau wawasan kepada pembudidaya terkait instalasi akuaponik.

\section{Penyuluhan program}

Penyuluhan program meliputi koordinasi dan sosialisasi program pada kelompok sasaran. Penyuluhan program ini dilaksanakan untuk memberikan pengetahuan kepada para pembudidaya atau kelompok sasaran mengenai usaha berkebun dengan teknologi instalasi akuaponik di pekarangan rumah dengan menggunakan model NFT (Nutrient Film Technique) yang meliputi metode menggabungkan budidaya tanaman sayuran tanpa menggunakan tanah (soiless culture) dan teknik membudidayakan ikan dengan system resirkulasi air dari akar tanaman, dengan harapan agar sasaran kelompok memiliki pengetahuan yang cukup terkait program ini sehingga program ini dapat berjalan dengan baik dan lancar.

\section{Pelatihan Program}

Untuk meningkatan pengetahuan, keterampilan, teknologi dan manajemen dalam pengelolaan usaha berkebun dengan teknologi instalasi akuaponik di pekarangan rumah dengan menggunakan model NFT (Nutrient Film Technique) yang meliputi metode menggabungkan budidaya tanaman sayuran tanpa menggunakan tanah (soiless culture) dan teknik membudidayakan ikan dengan system resirkulasi air dari akar tanaman, maka dilakukan pelatihan. Pelatihan dilaksanakan dengan menggunakan Metode yang digunakan adalah Focus Group Discusion (FGD) dengan memberikan informasi atau wawasan kepada pembudidaya dengan penekanan pada model 
komunikasi dua arah dengan pola tukar menukar pengalaman, diskusi kelompok, dan demonstrasi yang dilaksanakan dalam bentuk klasikal. Adapun materi pelatihan sebagai berikut :

- Teknik budidaya akuaponik model NFT (Nutrient Film Technique).

- Manajemen kewirausahaan, analisis hasil usaha dan pemasaran produk.

\section{Persiapan dan Pembuatan sistem akuaponik model NFT (Nutrient Film Technique)}

Pembuatan akuaponik model NFT (Nutrient Film Technique) dilakukan dengan menggunakan 2 buah kolam tendon yang akan diisi benih ikan nila sebanyak 1000 ekor, dengan masing masing kolam tendon akan diberikan pipa pvc 3" sebanyak 5 lonjor sebagai wadah menanam sayuran serta peralatan-peralatan lain untuk menunjang kegiatan. Sayuran yang akan dibudidayakan adalah tanaman yang dapat dimanfaatkan untuk kebutuhan sehari-hari dan memiliki pasar di daerah tersebut sehingga dapat menjadi komoditas ekonomi keluarga seperti tanaman jenis sawi, dan selada.

\section{Pembinaan dan Pendampingan}

Pada program pembinaan dan pendampingan, kelompok sasaran dibina secara intensif oleh para tim penyuluhan mulai dari proses pembuatan akuaponik, pemeliharaan sayuran dan ikan yang dibudidayakan dan menghitung analisis hasil usaha budidaya. Tujuan pembinaan adalah untuk membantu memecahkan masalah-masalah yang terjadi dalam pengelolaan usaha berkebun dengan teknologi instalasi akuaponik model NFT (Nutrient Film Technique) dan teknik membudidayakan ikan dengan system resirkulasi air dari akar tanaman, baik masalah teknis usaha maupun masalah manajemen kelompok. Dengan program ini, diharapkan masyarakat di Desa Karang Bajo lebih mandiri dalam mengembangkan usaha budidaya ikan yang sudah ditekuni sejak lama. Selain itu, adanya program pembinaan dan pendampingan dapat menambah pendapatan keluarga, karena mereka mendapat pengetahuan dan keterampilan dalam manajemen kewirausahaan.

\section{HASIL DAN PEMBAHASAN}

Kegiatan penyuluhan di desa Desa Gontoran Kecamatan Lingsar Kabupaten Lombok Barat berjalan lancar, masyarakat cukup antusisas dengan kegiatan penyuluhan ini, terlihat dari banyaknya peserta yang hadir mengikuti kegiatan penyuluhan. Penyuluhan ini dilakukan dengan mengumpulkan para peserta yang merupakan pembudidaya ikan nila. Informasi yang diberikan kepada pembudidaya dilakukan dengan metode Focus Group Discussion (FGD) dengan memberikan informasi atau wawasan kepada pembudidaya dengan penekanan pada model komunikasi dua arah dengan pola tukar menukar pengalaman, diskusi kelompok, dan demonstrasi yang dilaksanakan dalam bentuk klasikal (Gambar 1). Adapun materi pelatihan yang disampaikan mulai dari pemaparan teknik budidaya akuaponik model NFT (Nutrient Film Technique), dilanjutkan dengan membahas manajemen kewirausahaan, analisis hasil usaha dan pemasaran produk. 

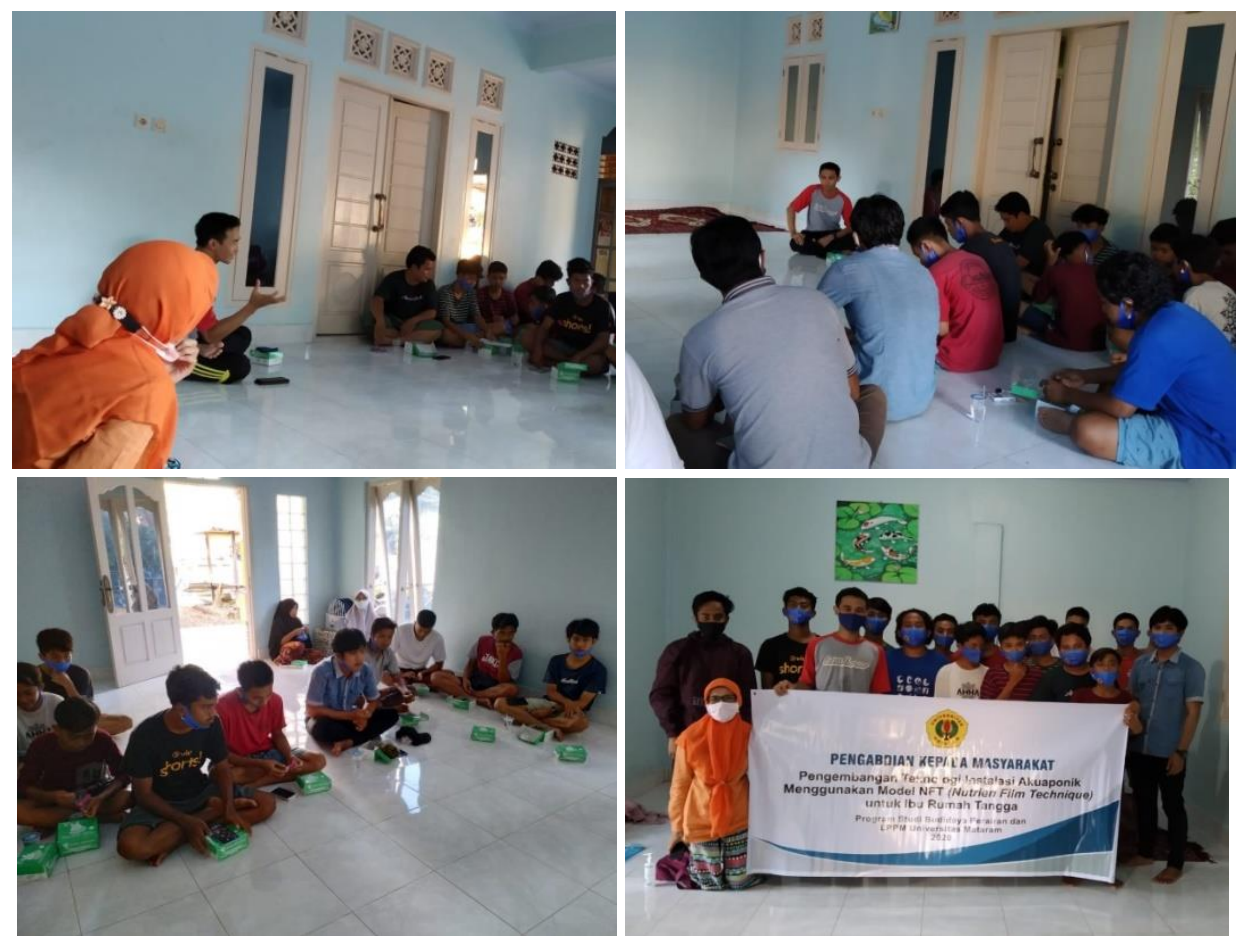

Gambar 1. Kegiatan penyuluhan (Dokumentasi pribadi, 2020)

Setelah kegiatan penyuluhan, para pembudidaya diberikan pendampingan dan pelatihan secara intensif oleh para tim penyuluhan mulai dari proses pembuatan akuaponik, pemeliharaan sayuran dan ikan yang dibudidayakan dan menghitung analisis hasil usaha budidaya. Tujuan pembinaan adalah untuk membantu memecahkan masalah-masalah yang terjadi dalam pengelolaan usaha berkebun dengan teknologi instalasi akuaponik model NFT (Nutrient Film Technique) dan teknik membudidayakan ikan dengan system resirkulasi air dari akar tanaman, baik masalah teknis usaha maupun masalah manajemen kelompok.

Pada kegiatan ini pembuatan akuaponik model NFT (Nutrient Film Technique) dilakukan dengan menggunakan 2 buah kolam tendon yang diisi benih ikan nila sebanyak 1000 ekor, dengan masing masing kolam tendon diberikan pipa pvc 3" sebanyak 5 lonjor sebagai wadah menanam sayuran serta peralatan-peralatan lain dalam menunjang kegiatan. Sayuran yang dibudidayakan adalah tanaman yang dapat dimanfaatkan untuk kebutuhan sehari-hari dan memiliki nilai pasar di daerah tersebut sehingga dapat menjadi komoditas ekonomi keluarga seperti tanaman jenis sawi, dan selada. Adapun ikan yang dipelihara dalam kegiatan ini adalah ikan nila (Oreochromis niloticus). Tujuan dari pemilihan ikan nila untuk dibudidayakan pada teknologi akuaponik sesuai dengan pernyataan Maulana (2015), yang menyatakan bahwa ikan nila memiliki beberapa keunggulan dibandingkan dengan ikan air tawar lainnya, yakni mudah untuk dibudidayakan, memiliki nilai ekonomi yang cukup tinggi, toleran terhadap kualitas air yang rendah, mudah untuk dibiakkan, dan tahan terhadap serangan penyakit.

Dalam kegiatan budidaya dengan teknologi akuaponik ini cukup menguntungkan. Hal ini disebabkan karena adanya kombinasi akuakultur dan hidroponik yang dapat memelihara ikan dan tanaman dalam satu sistem yang saling terhubung dan membentuk simbiosis mutualisme (Rakocy et al., 2006). Sehingga pembudidaya dapat memperoleh keuntungan yang lebih tinggi dibandingkan dengan hanya melakukan kegiatan budidaya ikan biasa. Pada penerapan teknologi akuaponik semua nutrisi yang dibutuhkan oleh tanaman berasal dari limbah ikan. Menurut Ardha (2018), kolam 
pemeliharaan ikan kaya akan humus dan sisa pakan yang banyak mengandung hara ( $\mathrm{N}, \mathrm{P}$ dan $\mathrm{K}$ ), sehingga dapat menunjang pertumbuhan dan perkembangan tanaman. Mekanisme kerja teknologi akuaponik mereduksi amonia dengan menyerap air buangan budidaya atau air limbah dari kolam ikan dengan menggunakan akar tanaman yang berfungsi sebagai biofilter sehingga amonia yang terserap mengalami proses oksidasi dengan bantuan oksigen dan bakteri nitrifikasi, kemudian amonia akan diubah menjadi nitrat (Widyastuti, 2008). Menurut Nugroho \& Sutrisno (2008), tanaman dapat mereduksi ammonia hingga 90\%, sehingga air limbah dari kegiatan budidaya ikan masih layak digunakan kembali sebagai media pemeliharaan ikan dan dapat meminimalisasi pergantian air selama proses budidaya berlangsung. Selain adanya ketersediaan unsur hara, jenis tanaman dan ikan, teknik irigasi juga berpengaruh terhadap berhasilnya sistem akuaponik. Pada kegiatan ini digunakan teknik irigasi NFT (Nutrient Film Technique) yang merupakan bentuk teknik hidroponik aktif, teknik tersebut dapat digunakan dengan mudah dan efisien untuk budidaya tanaman karena system resirkulasi air dapat terhubung dengan baik mengairi seluruh akar tanaman.

Dengan adanya kegiatan ini, diharapkan masyarakat di Desa Gontoran lebih mandiri dalam mengembangkan usaha budidaya ikan yang sudah ditekuni sejak lama, dan dapat meningkatkan pendapatan keluarga. Selain itu, adanya program pembinaan dan pendampingan dapat menambah wawasan dan keterampilan para pembudidaya dalam memanajemen usaha yang mereka jalani.

\section{KESIMPULAN DAN SARAN}

Penyuluhan mengenai teknik budidaya akuaponik dengan mengkombinasikan sistem akuakultur dan hidroponik yang dapat memelihara ikan dan tanaman dalam satu sistem yang saling terhubung dapat membantu meningkatkan pendapatan para pembudidaya. Selain itu juga dapat meningkatkan keterampilan dan wawasan para pembudidaya terkait system budidaya berkelanjutan dan manajemen wirausaha yang tepat.

Adapun saran untuk kegiatan pengabdian kedepannya diharapkan teknologi budidaya akuaponik yang digunakan lebih dikembangkan dan dikombinasikan dengan tanaman jenis lainnya.

\section{UCAPAN TERIMA KASIH}

Terima kasih kepada LPPM Universitas Mataram yang telah mewadahi dan membiayai kegiatan pengabdian ini.

\section{DAFTAR PUSTAKA}

Dauhan, R. E. S., Eko, E., Saparmono. 2014. Efektifitas Sistem Akuaponik dalam Mereduksi Konsentrasi Amonia Pada Sistem Budidaya Ikan. Jurnal Rekayasa dan Teknologi Budidaya Perairan, 3 (1) : 297-302.

Maulana I. 2015. Nila akuaponik, Lima alasan ikan ini terbaik untuk akuaponik. Diunduh tanggal 19 Mei 2020. Available from: URL: HYPERLINK http://gardenaquaponic.com/id/2015/11/26/ nilaakuaponik

Nugroho E. \& Sutrisno. 2008. Budidaya Ikan dan Sayuran dengan Sistem Akuaponik. Jakarta : Penebar Swadaya $68 \mathrm{hlm}$.

Nugroho, R. A., Lilik, T. P., Diana, C. 2012. Aplikasi Teknologi Aquaponic pada Budidaya Ikan Air Tawar Untuk Optimalisasi Kapasitas Produksi.Jurnal Saintek Perikanan, 8 (1) : 46-51.

Rakocy. 2006. Development of an Aquaponic System for the Intensive Production of Tilapia and Hydroponic Vegetables. University of the Virgin Island Agricultural Experiment Station. Kingshill, U.S Virgin Island. 
Saparianto, C. dan Susiana, R. 2014. Panduan Lengkap Budidaya Ikan dan Sayuran dengan Sistem Akuaponik. Lily Publisher. Yogyakarta.

Septia, E. D., Livia, W., Nur, O. A. 2018. Pemberdayaan Ibu Rumah Tangga denga Teknologi Budidaya Aquavertikulture pada Lahan Sempit.Jurnal Pengabdia Kepada Masyarakat, 1 (1) : 30-35.

Somerville, C., M. Cohen, E. Pantanella, A. Stankus, and A. Lovatelli. 2014. Smallscale Aquaponics Food Production :Integrated Fish and Plant Farming. FAO. Rome.

Sulistiyo, M. A. B., Taufiqurrahman., Djohar, N. 2016. Teknologi Akuaponik Untuk Memperkuat Ekonomi Warga Rw 10 Kelurahan Bandungrejosari Kota Malang. SenasPro UMM. Malang.

Widyastuti Y. R. 2008. Peningkatan produksi air tawar melalui budidaya ikan sistem akuaponik. Prosiding Seminar Nasional Limnologi IV LIPI. Bogor: 62-73. 